of a V-shaped cutting ten feet deep. The channel itself is four feet wide, with a bottom of red earthenware tiles. No conduit of this type had previously been found in this part of Roman Britain. It appears to have gone out of use in the second century A.D. The foundations of the three-roomed Roman building have now been cleared, and show the remarkable and unusually wide doorway, which is seven feet across.

\section{Prehistoric Civilization of Northern France}

THE party of archæologists deputed by the Society of Antiquaries of London to carry out archæological investigations in northern France is now at work in Brittany and western Normandy under the direction of Dr. R. E. Mortimer Wheeler. The expedition has been undertaken with the good will of, and under a permit from the French authorities, in accordance with an agreement into which the Society of Antiquaries entered with them last year. This investigation will constitute the major undertaking for the time being of the Society in archæological research in the field, taking the place of the excavation of Maiden Castle, Dorchester, upon which it was engaged, with Dr. Wheeler as its director, for some years. The purpose of the investigation in France is to search for evidence of the cross-channel origin of the eivilization of southwestern Britain in the later prehistoric period, and more especially of the fortified towns which appear there suddenly in a state of mature development, but of which the source is uncertain. This is a department of investigation in France which French archæologists have left virtually untouched. The programme of the investigators is in the first place to map the distribution of pre-Roman earthworks of the Maiden Castle type in north-western France, and secondly to ascertain by trial excavation on selected sites what cultures went to make up these Continental works. The first centre which has been chosen for excavation is Huelgoat, a well-known site in the pine forest about twenty miles south of Morlaix, where a camp nearly a mile in length is under examination. It is seen to have been built in the first century B.c. on the eve of the Roman conquest of northern France. The rampart, fifteen feet high, is faced with stone and bonded with lacing timbers. The ditch is in part cut out of the granite rock. The search for other sites has progressed so far as to show that the great Wessex fortified sites did not originate in Finistère, though certain smaller fortified enclosures in that department can be paralleled in Cornwall. Investigation will shortly move farther east to a large camp in the neighbourhood of Avranches.

\section{Fungus Diseases of Animals}

A NEW journal devoted to the fungus diseases of man and other animals has recently commenced publication (Mycopathologia, Den Haag, Dr. W. Junk, 18 Dutch florins per volume, 1, Fase. 1, 80 pp. May 1938). The publication is international; it is edited in Italy and printed in Holland; the United States provides the first number with several authors, whilst the list of collaborators is long and geo- graphically extensive. R. Ciferri, director of the Botanical Laboratory of the Faculty of Agriculture in the University of Florence, and P. Redaelli, director of the Institute of Pathological Anatomy in the University of Padua, are the joint editors. They contribute the first paper on "A New Hypothesis on the Nature of Blastocystis". This organism shows more affinities with certain algæ than with sporogenous yeasts, and the general biologist will welcome the discovery of a further link between fungi and algæ. Classification of fungi belonging to the genus Actinomyces is considered by E. Baldacci of Padua. The rest of the papers in the present number demonstrate the wide scope and outlook of the journal. The papers are all scientifie contributions to a littleknown section of mycology, and a "Bibliographia Mycopathologia" of references to work published in 1937 adds further utility. The production is excellent, both of type and plates, and the volume should supply a particularly welcome quota of knowledge in Great Britain, where fungal diseases of man are apparently not common enough to provoke research on a large scale.

\section{Advances in Printing Telegraph Technique}

IT is shown in a paper by A. E. Thompson, published in Electrical Communication of April, that at no period in the history of the telegraph has there been such revolutionary improvements in methods and equipment or such rapid development and expansion in its service to the community as during the last ten years. The progress was initiated by the introduction of teleprinter systems, which by providing instruments requiring no telegraphic skill on the part of the operators have completely changed the outlook of telegraphy and greatly stimulated development in all its branches. Teleprinters are superseding all the older types of machine telegraphic apparatus. Even hand Morse working, which has been the backbone of telegraphy for more than a century, has now been abandoned in the British telegraph service, the bulk of the traffic being handled by Creed teleprinters. Similar developments are taking place in other countries. A description is given of the new Creed No. 10 tape teleprinter. The improvements achieved are trustworthy service at $\mathbf{8 5}$ words per minute, reduced costs, quiet operation and reduced size. Maintenance costs have been reduced by evolving mechanisms with a breakdown speed exceeding 100 words per minute. The printer operates continuously for 300 hours without requiring lubrication. Ballbearings and oil-impregnated bearings as well as sliding surfaces lubricated by means of oil reservoirs are used. This machine can be used by telegraph administrations and private companies as well as by high-speed news and ticker services.

\section{History of Maize-Breeding}

IN a recent lecture given at the Michigan State College, Mr. Henry A. Wallace, the United States Secretary of Agriculture, traced the history of maize or corm breeding and pointed out that up to 1890 the farmers of the corn-belt had not been superior to their Indian predecessors as corn breeders, the chief 